\title{
ワークショップ I
}

\section{6. 血液検査結果より重症例と判定された肺炎の検討}

\author{
石川 信泰 ${ }^{1)}$ ，菱木はるか ${ }^{2)}$ ，石和田稔彦 ${ }^{2}$
}

( ${ }^{1)}$ 千葉市立青葉病院小児科), ( ${ }^{2}$ 千葉大学大学院小児病態学)

はじめに

肺炎患者の治療を外来あるいは入院で行う か, 抗菌薬が必要かどうか, 必要なら抗菌薬を 経口または経静脈的に行うかなどを判断する上 で, 肺炎の重症度を判定することは重要である。 小児呼吸器感染症診療ガイドライン $2004^{1)}$ で は，表 1 に示すように肺炎の重症度は身体所見 および検査所見から判定する。今回血液検査所 見から重症と判定さた症例の実態を検討した。

\section{対象および方法}

平成 17 年 4 月から 18 年 8 月までの 17 ケ月間
に千葉市立青葉病院小児科入院した肺炎症例に ついて検討した。検討期間中に肺炎症例は112 例みられた。このうち表 1 に示される血液検査 所見における重症例の基準である CRP> $15 \mathrm{mg} / \mathrm{dL}$ の症例は 8 例, 好中球数 $>10,000 / \mu \mathrm{L}$ の症例は 35 例, 好中球数 $<500 / \mu \mathrm{L}$ の症例はみ られなかった。CRP と白血球数がともに重症 例の基準を満足したものは 7 例で, 表 2 に内訳 を示した。全て基礎疾患のない乳幼児であった。 2 例に抗菌薬の前投与があった。この 7 例につ いて, 他の重症度判定項目, 病因検索, 治療抒 よび予後について診療録の記載より後方視的に 検討した。

表 1 小児市中肺炎一身体所見・検査所見による重症度判定一

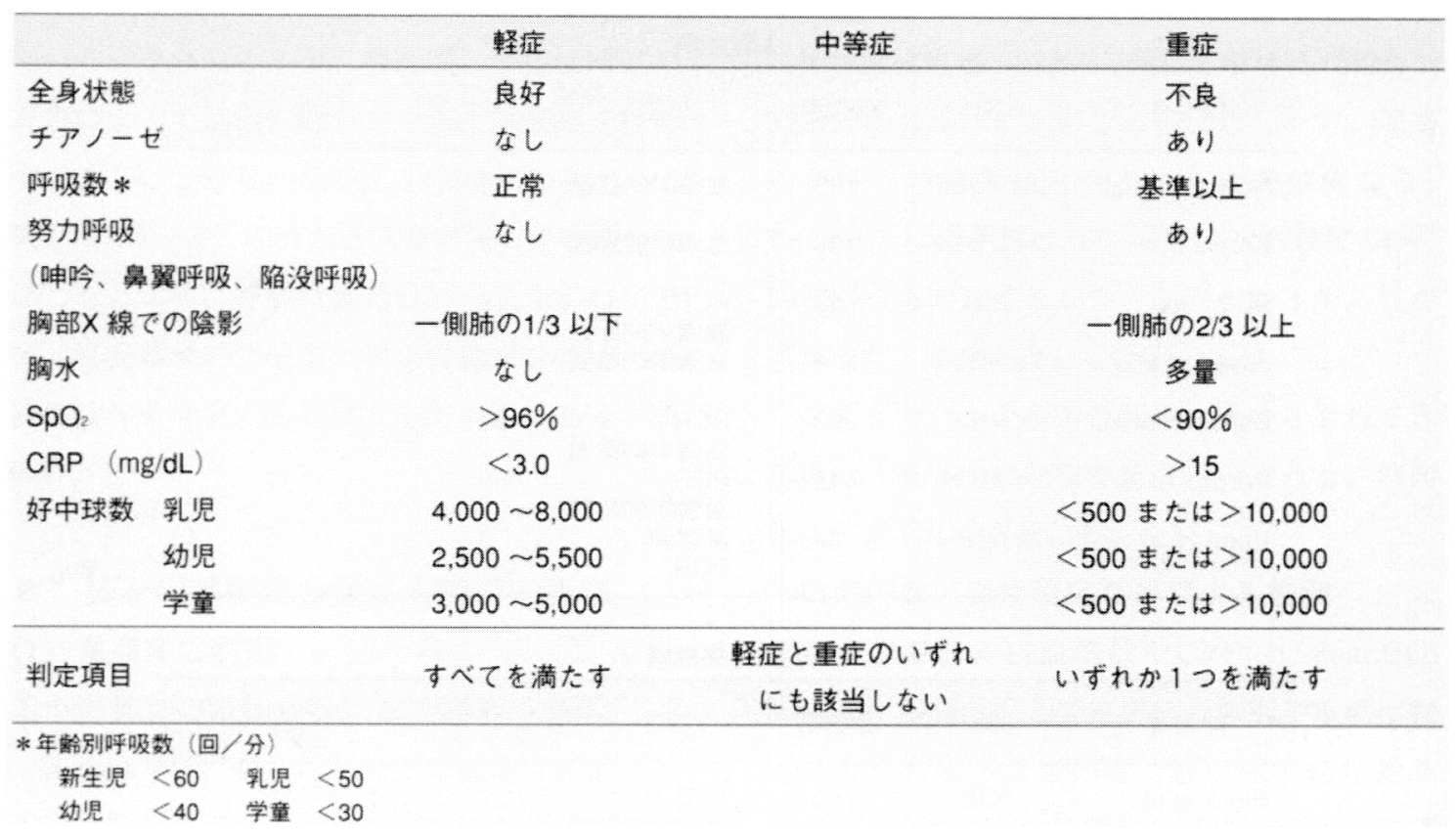


表 2 症例の内訳

\begin{tabular}{|c|c|c|c|c|c|}
\hline 症例 & 性別 & 月齢 & 基礎疾患 & 病日 & $\begin{array}{c}\text { 抗菌薬 } \\
\text { 前投与 }\end{array}$ \\
\hline 1 & $\mathrm{~F}$ & 8 & なし & 5 & なし \\
\hline 2 & $\mathrm{~F}$ & 9 & なし & 5 & なし \\
\hline 3 & $\mathrm{M}$ & 35 & なし & 3 & なし \\
\hline 4 & $\mathrm{~F}$ & 41 & なし & 6 & $\mathrm{AZM}$ \\
\hline 5 & $\mathrm{~F}$ & 45 & なし & 5 & なし \\
\hline 6 & $\mathrm{M}$ & 59 & なし & 5 & CAM \\
\hline 7 & $\mathrm{M}$ & 65 & なし & 3 & なし \\
\hline
\end{tabular}

病日:発熱した日を病日1

表 3 重症度判定項目

\begin{tabular}{|c|c|c|c|c|c|c|c|c|c|}
\hline 症例 & $\begin{array}{c}\text { 好中球数 } \\
(\mu \mu \mathrm{L})\end{array}$ & $\begin{array}{c}\mathrm{CRP} \\
(\mathrm{mg} / \mathrm{dL})\end{array}$ & X線所見 & 胸水 & $\mathrm{SpO}_{2}$ & 全身状態 & チアノーゼ & $\begin{array}{c}\text { 呼吸数 } \\
(/ \text { 分 })\end{array}$ & 努カ性呼吸 \\
\hline 1 & 13,000 & 21.2 & 右 $\mathrm{S} 4$ & なし & $96 \%$ & 良好 & なし & 48 & なし \\
\hline 2 & 18,200 & 30.1 & 右 $\mathrm{S} 3$ & なし & 未記載 & 良好 & なし & 42 & なし \\
\hline 3 & 27,700 & 19.4 & 左 S8 & なし & $96 \%$ & 良好 & なし & 未記載 & なし \\
\hline 4 & 32,100 & 17.2 & 右 S3 & なし & 未記載 & 良好 & なし & 25 & なし \\
\hline 5 & 14,100 & 22.3 & 右 S3 & なし & $96 \%$ & 良好 & なし & 35 & なし \\
\hline 6 & 23,400 & 21.2 & 右 $\mathrm{S} 6$ & なし & $96 \%$ & 良好 & なし & 35 & なし \\
\hline 7 & 16,400 & 18.7 & 右 $\mathrm{S} 3$ & なし & $94 \%$ & 良好 & なし & 50 & なし \\
\hline
\end{tabular}

\section{結果}

表 3 に各症例の重症度判定項目についてまと めた。血液検査で好中球数は $13,300 ３ 2,100 /$ $\mu \mathrm{L}, \mathrm{CRP} は 17.2 \sim 30.1 \mathrm{mg} / \mathrm{dL}$ であった。全例 胸部 X 線での陰影の程度広がりは一区域のみ で，重症度の基準は満たさなかった。また $\mathrm{SpO} 2 お$ よび身体所見にて重症度の基準を満た したのは症例 7 のみであった。

表 4 に病因検査についての結果を示した。血 液培養で陽性となったものはなかった。洗浄喀 痰培養の結果では, 肺炎球菌が有意であった例 が 4 例（症例 $3 ， 4,5,7$ ), 肺炎球菌とイ ンフルエンザ菌の 2 菌種が有意であった症例が 1 例 (症例 1 ), 病原を有する菌と常在菌が同 程度の発育であり, 有意菌と判定できなかった ものが 2 例（症例 2，6）であった。迅速検査 として喀痰塗抹検査 6 例, 肺炎球菌尿中抗原検 査 4 例行っている。塗抹検査では肺炎球菌と考
えるグラム陽性双球菌を有意に認めたものが 5 例, 肺炎球菌尿中抗原の陽性であったものが 4 例みられた。塗抹結果が培養結果と不一致であ った症例 6 は前投薬をうけていた。

表 5 に治療および治療後の経過をまとめた。 全例 ampicillin (ABPC) を 1 日量約 $100 \mathrm{mg} / \mathrm{kg}$ の投与で治療開始した。治療開始 $1 \sim 2$ 日後に は解熱した。治療開始後 $2 \sim 3$ 日目に検査を行 い全例好中球数は正常化し, CRP 值は治療前 の15.4〜34.9\%に改善した。表に示さなかった が, 胸部 X 線でも全例改善傾向がみられた。 治療期間は 5 日間として全例治癒した。

\section{考察}

肺炎はウィルス性肺炎, 非定型肺炎, 細菌性 肺炎等様々であり, 治療を選択するに当たって はこれらの鑑別が必要である。血液検査により これらを鑑別することは以前より行われてきた 2,3)。小览呼吸器感染症診療ガイドライン 2004 
表 4 細菌学的検査結果

\begin{tabular}{|c|c|c|c|c|}
\hline 症例 & 血液培養 & 洗浄喀痰培養 & 喀痰塗抹 & $\begin{array}{l}\text { 肺炎球菌 } \\
\text { 尿中抗原 }\end{array}$ \\
\hline 1 & 陰性 & PSSP1+,Hi1+ & GPD3+ & 未検査 \\
\hline 2 & 陰性 & BLNAR1+、常在菌1+ & 陰性 & 陽性 \\
\hline 3 & 陰性 & PISP1+ & GPD4+ & 未検査 \\
\hline 4 & 陰性 & PSSP2+ & GPD3+ & 陽性 \\
\hline 5 & 陰性 & PSSP2+ & 陰性 & 陽性 \\
\hline 6 & 陰性 & BLNAI3+,常在菌3+ & GPD3+ & 未検査 \\
\hline 7 & 陰性 & PSSP1+ & GPD3+ & 陽性 \\
\hline & $\begin{array}{l}\text { PSSP:ペニシ } \\
\text { PISP:ペニシ } \\
\text { Hi:インフルI } \\
\text { BLNAR: } \beta \text { ラ } \\
\text { GPD :グラム }\end{array}$ & $\begin{array}{l}\text { リン感受性肺炎球菌 } \\
\text { リン中等度耐性肺炎球菌 } \\
\text { シザ菌 (感受性未検查) } \\
\text { クタマーゼ陰性アンピシリ } \\
\text { 楊性双球菌 }\end{array}$ & 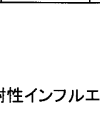 & ザ苗 \\
\hline
\end{tabular}

では身体所見および検査所見から判定し，血液 検査の項目としては好中球数と CRP 值を用い ている。今回の検討では、好中球数のほうが $\mathrm{CRP}$ 值よりも判定基準を満たす症例が多くみ られた。今回は好中球数と CRP 值ともに重症 と判定さた 7 症例のみついて詳細に検討を加え た。これら 7 例で血液検查以外の他の項目でも 判定基準を満たしたものは 1 例のみであった。 すなわち血液検査で重症判定されても，肺炎の 広がりや，全身状態や呼吸状態とは関連しなか つた。

肺炎の原因検索として gold standard とされ る血液培養を全例に行ったが，抗菌薬の前投与 は2 例のみであったにもかかわらず陽性例はな かった。これまでの報告通り血液培養では検出 感度の悪いことが示された。気管支肺感染症の 原因菌決定の方法として洗浄喀痰培養 ${ }^{4)}$ が小 児呼吸器感染症診療ガイドライン2004にも示さ れている。今回洗浄喀痰培養抒よび塗抹検査を 全例に行い，洗浄喀痰培養結果では 5 例で有意 に菌が検出され，5例とも肺炎球菌の関与が示 された。塗抹検査では 4 例が培養結果と一致し た。細菌培養は結果を得るには少なくとも 1 日 を要するため，この結果を待たずに経験的な抗 菌薬治療が開始され，広域の抗菌薬が用いられ ることも多い。さらには院内に細菌検査室を持 たない病院も増えており, 細菌培養検査結果を 得るのに数日要すため経験的な広域抗菌薬のま ま治療が続けられる。塗抹検査は迅速に結果を 出すことができ，抗菌薬の選択を狭めることが
表 5 治療および経過

\begin{tabular}{|c|c|c|c|c|c|c|}
\hline & \multirow{2}{*}{$\begin{array}{l}\text { 抗菌薬 } \\
\text { (投与日数) }\end{array}$} & \multirow{2}{*}{$\begin{array}{c}\text { 解熱まで } \\
\text { の日数 }\end{array}$} & \multicolumn{3}{|c|}{ 治療開始後検査 } & \multirow{2}{*}{ 予後 } \\
\hline & & & 検査日 & $\begin{array}{c}\text { 白血球数 } \\
(/ \mu \mathrm{L})\end{array}$ & $\begin{array}{l}\text { CRP } \\
(\mathrm{mg} / \mathrm{dL})\end{array}$ & \\
\hline 1 & $\mathrm{ABPC}(5)$ & 2日 & 2日後 & 7,700 & 6.9 & 治癒 \\
\hline 2 & $\operatorname{ABPC}(5)$ & 1日 & 3日後 & 4,600 & 4.6 & 治瘺 \\
\hline 3 & $\operatorname{ABPC}(5)$ & 1日 & 3日後 & 7,800 & 3.3 & 治癒 \\
\hline 4 & $\operatorname{ABPC}(5)$ & 1日 & 3日後 & 5,400 & 5.4 & 治癒 \\
\hline 5 & $\operatorname{ABPC}(5)$ & 1日 & 3日後 & 5,700 & 4.8 & 治癒 \\
\hline 6 & $A B P C(5)$ & 1日 & 3日後 & 7,500 & 7.4 & 治癒 \\
\hline 7 & ABPC (5) & 1日 & 3日後 & 4,900 & 3.4 & 治癒 \\
\hline
\end{tabular}

できる。著者らは小児の下気道感染症の迅速診 断法としての有用性を示している ${ }^{5)}$ 。成人市中 肺炎診療ガイドライン ${ }^{6)}$ において, 塗抹検査 は初期治療に役立つ微生物検査（迅速検査）の 中でも簡便で外来，ベッドサイドでも実施可能 な検査として位置づけられている。グラム染色 は精度が実施者の経験に左右されやすいものと されてはいるが，初期研修の経験目標にもなっ ており，今後十分活用されることを願いたい。 なお常在菌の混入する上咽頭スワブなどでは塗 抹検査を行う意味はなく, 喀痰を採取し洗浄す ることで初めて塗抹検査が意義を持つ。成人市 中肺炎診療ガイドラインでは肺炎球菌尿中抗原 検査も初期治療に役立つ微生物検査 (迅速検査) として挙げられている。今回は 4 例に検査を行 い，3例で洗浄喀痰培養結果と一致した。ただ し本検査では咽頭保菌者での疑陽性も報告され て扣り ${ }^{7)}$ その有用性にはさらに検討を要する と考えられる。

小児呼吸器感染症診療ガイドライン2004では 抗菌薬の効果判定は $2 \sim 3$ 日後に行うとし, 一 般細菌では概ね解熱後 3 日を目安に抗菌薬投与. を中止することが可能であると述べている。一 方成人市中肺炎診療ガイドラインでは効果判定 基準として具体的に(1)解熱(2)末梢血液白血球数 増加の改善(3) CRP の改善(4)胸部 X 線陰影の明 らかな改善の 4 項目をあげている。今回の症例 では抗菌薬開始 $1 \sim 2$ 日で解熱し， 2 3 日目 に行った血液検査では改善がみられた。抗菌薬 は全例 5 日間すなわち解熱後 $3 \sim 4$ 日使用し全 例治癒した。さらに短期の治療でもよいのか, 経口抗菌薬へのスイッチ療法は必要かあるいは 可能かといった問題は症例を重ねて検討をする 
必要がある。

\section{文献}

1）上原すが子, 砂川慶介監修: 小児呼吸器感染 症診断ガイドライン2004. 協和企画, 2004, 東京

2) Ponka A, Sarna S : Differential diagnosis of viral, mycoplasmal and bacteraemic pneumococcal pneumonias on admission to hospital. Eur J Resppir Dis 64 : 360-363, 1983

3 ) Korppi M, Kroger L : C-reactive protein in viral and bacterial respiratory infection in children.Scand J Infect Dis 25 : 207-213, 1993
4) 上原すぶ子：小児呼吸器疾患の診断法. 微生 物学的検查. 細菌. 小林 登監修: 新小児科 学大系 $9 A$ 小児呼吸器病学 I. 中山書店, 東 京. p240-261，1982

5 ）杉岡竜也, 石川信泰, 郡 美夫, 他: 洗浄喀 痰塗抹による起因菌の迅速診断. 小坚科 40 ： 1537-1543， 1999

6 ）日本呼吸器学会呼吸器感染症に関するガイド ライン作成委員会：成人市中肺炎診療ガイド ライン。 日本呼吸器疾患学会, 東京, 2007

7 ）坂田 宏：小児における肺炎球菌抗原の半定 量化の試み。小児感染免疫18（1）:19-24 